\title{
Synthesis, Characterization, X-Ray Crystal Structure, and Antimicrobial Activity of 1,1'-(3,4-Diphenylthieno[2,3-b] thiophene-2,5-diyl)diethanone
}

\author{
Yahia Nasser Mabkhot, ${ }^{1}$ Fahad D. Aldawsari, ${ }^{1,2}$ S. S. Al-Showiman, ${ }^{1}$ \\ Assem Barakat, ${ }^{1,3}$ M. Iqbal Choudhary, ${ }^{1,4}$ and Sammer Yousuf ${ }^{4}$ \\ ${ }^{1}$ Department of Chemistry, College of Science, King Saud University, P.O. Box 2455, Riyadh 11451, Saudi Arabia \\ ${ }^{2}$ King Abdulaziz City for Science and Technology, P.O. Box 6086, Riyadh 11442, Saudi Arabia \\ ${ }^{3}$ Department of Chemistry, Faculty of Science, Alexandria University, P.O. Box 426, Ibrahimia, Alexandria 21321, Egypt \\ ${ }^{4}$ H.E.J. Research Institute of Chemistry, International Center for Chemical Sciences, University of Karachi, Karachi 75270, Pakistan
}

Correspondence should be addressed to Yahia Nasser Mabkhot; yahia@ksu.edu.sa and Assem Barakat; ambarakat@ksu.edu.sa

Received 12 December 2013; Revised 9 February 2014; Accepted 24 April 2014; Published 11 May 2014

Academic Editor: C. Suresh Reddy

Copyright (C) 2014 Yahia Nasser Mabkhot et al. This is an open access article distributed under the Creative Commons Attribution License, which permits unrestricted use, distribution, and reproduction in any medium, provided the original work is properly cited.

Synthesis of 1,1'-(3,4-diphenylthieno[2,3-b]thiophene-2,5-diyl)diethanone (4) is reported here. The structure of compound 4 was deduced by ${ }^{1} \mathrm{H}$-NMR, ${ }^{13} \mathrm{C}$-NMR, FT-IR, MS, microanalysis, and single-crystal X-ray diffraction. Compound crystallizes in the monoclinic space group $P 21 / n$ with $a=9.3126(7) \AA, b=9.5867(7) \AA, c=20.2811(15) \AA, \alpha=90^{\circ}, \beta=95.436(2)^{\circ}, \gamma=90^{\circ}, V=$ $1802.5(2) \AA^{3}$, and $Z=4$. The molecules are packed in crystal structure by weak intermolecular C10-H10A $\cdots$ S 1 hydrogen bonding interactions. Compound 4 can be a useful intermediate for the synthesis of diphenylthieno[2,3-b]thiophene. Compound 4 was found to be active against Gram-positive bacteria (Bacillus subtilis and Staphylococcus pneumoniae) and Gram-negative bacteria (Escherichia coli) and also was found to be active against fungi (Aspergillus fumigatus and Candida albicans).

\section{Introduction}

Thienothiophenes skeletons are important in pharmaceutical research because of their versatile biological activities, such as antitumor, antiviral antibacterial, anticancer, antioxidant and $\beta$-glucuronidase and $\alpha$-glucosidase inhibition, antiglaucoma activity, and inhibitors of platelet aggregation properties [1-5]. Because of this thieno[2,3-b]thiophenes have been the focus of active research in recent years. We have the synthesis of certain bis-heterocycles containing thieno[2,3b] thiophene derivatives. The molecules that were prepared were found to be potent $\alpha$-glucosidase inhibitors $\left(\mathrm{IC}_{50}=\right.$ $14.1 \pm 0.28 \mu \mathrm{M}$ ) with manyfold more activity than the standard acarbose $\left(\mathrm{IC}_{50}=841 \pm 1.73 \mu \mathrm{M}\right)$. Indeed, another example incorporating thieno[2,3- $b$ ] thiophene core was found to be a potent $\beta$-glucuronidase inhibition $\left(\mathrm{IC}_{50}=0.003 \pm\right.$ $0.09 \mu \mathrm{M})$ several hundred fold more active than standard Dsaccharic acid 1,4-lactone $\left(\mathrm{IC}_{50}=45.75 \pm 2.16 \mu \mathrm{M}\right)[6,7]$.
The skeleton is identified as valuable scaffold for new heterocyclic compounds [8-11]. The structure of $1,1^{\prime}-(3,4-$ diphenylthieno[2,3-b] thiophene-2,5-diyl)diethanone (4) was unambiguously deduced by single-crystal X-ray diffraction technique. Compound $\mathbf{4}$ was also screened for in vitro antimicrobial activity.

\section{Experimental}

2.1. General. All the chemicals were purchased from various suppliers, including Sigma-Aldrich and Fluka, and were used without further purification, unless otherwise stated. All melting points were measured on a Gallenkamp melting point apparatus in open glass capillaries and are uncorrected. IR Spectrum was recorded as $\mathrm{KBr}$ pellets on a Nicolet 6700 FT-IR spectrophotometer. The NMR spectra were recorded on a Varian Mercury Jeol-400 NMR spectrometer. ${ }^{1} \mathrm{H}$ NMR $(400 \mathrm{MHz})$ and ${ }^{13} \mathrm{C}-\mathrm{NMR}(100 \mathrm{MHz})$ were run in 
deuterated dimethyl sulphoxide (DMSO- $d_{6}$ ). Chemical shifts $(\delta)$ are referred to in $p p m$ while $J$-coupling constants were represented in $\mathrm{Hz}$. Mass spectra were recorded on a Jeol of JMS-600 H. Elemental analysis was carried out on Elmer 2400 Elemental Analyzer, CHN mode. The single-crystal Xray diffraction measurements were performed using Bruker SMART APEXII CCD diffractometer.

\subsection{Preparation of $1,1^{\prime}-(3,4-D i p h e n y l t h i e n o[2,3-b]$ thiophene- 2,5-diyl)diethanone}

Method A. A mixture of 1,3-diphenylpropane-1,3-dione (1) $(22.4 \mathrm{~g}, 0.1 \mathrm{~mol})$ and anhydrous potassium carbonate $(25 \mathrm{~g})$ in DMF (30-40 mL) was stirred vigorously at room temperature for $5 \mathrm{~min}$; then carbon disulfide $(7.6 \mathrm{~mL}, 0.1 \mathrm{~mol})$ was added with continued stirring for $30 \mathrm{~min}$. The resulting reaction mixture was cooled in ice bath, and then chloroacetone $(18.5 \mathrm{~mL}, 0.2 \mathrm{~mol})$ was added with continued stirring for $15 \mathrm{~min}$. Then cooling bath was subsequently removed and the mixture was stirred for further $30 \mathrm{~min}$. The solid product was collected by filtration and washed with water and dried crude product.

Method B. A mixture of 1,3-diphenylpropane-1,3-dione (1) $(22.4 \mathrm{~g}, 0.1 \mathrm{~mol})$ and NaOEt $(2 \mathrm{~mol} \mathrm{Na}$ in $30-40 \mathrm{~mL}$ absolute $\mathrm{EtOH}$ ) was stirred vigorously at room temperature for $5 \mathrm{~min}$, and then carbon disulfide $(7.6 \mathrm{~mL}, 0.1 \mathrm{~mol})$ was added with continued stirring for $30 \mathrm{~min}$. The resulting reaction mixture was cooled in ice bath, and then chloroacetone $(18.5 \mathrm{~mL}$, $0.2 \mathrm{~mol}$ ) was added with continued stirring for $15 \mathrm{~min}$; then cooling bath was subsequently removed and the mixture was stirred for further $30 \mathrm{~min}$. The solid product was collected by filtration and washed with water and dried $[12,13]$.

Yield: $75 \%$; m.p. $265^{\circ} \mathrm{C}$; IR $\left(\nu_{\max }\right): 1637(\mathrm{C}=\mathrm{O}) \mathrm{cm}^{-1}$; ${ }^{1} \mathrm{H}-\mathrm{NMR}\left(400 \mathrm{MHz}, \mathrm{DMSO}-d_{6}\right): \delta 1.74\left(\mathrm{~s}, 6 \mathrm{H}, \mathrm{CH}_{3}\right), 7.00-$ $7.04(\mathrm{~m}, 10 \mathrm{H}, \mathrm{Ph}) ;{ }^{13} \mathrm{C}-\mathrm{NMR}\left(100 \mathrm{MHz}, \mathrm{DMSO}-d_{6}\right): \delta 31.37$ $\left(\mathrm{COCH}_{3}\right), 191.3(\mathrm{C}=\mathrm{O}), 129.23,129.55,129.87,134.79,138.82$, 141.84, 147.68 (Ar-C); MS m/z (\%): 376 [M+, 60\%], 300 (100), 226 (37), 184 (14); anal. calcd. for $\mathrm{C}_{22} \mathrm{H}_{16} \mathrm{O}_{2} \mathrm{~S}_{2}$ : C, 70.18; $\mathrm{H}$, 4.28; S, 17.03; found: C, 70.07; H, 4.44; S, 17.11 .

2.3. Crystal Structure Determination. Slow evaporation of glacial acetic acid solution of pure compound $\mathbf{4}$ yielded colorless crystals. A crystal of dimensions $0.54 \times 0.53 \times$ $0.30 \mathrm{~mm}$ was selected for X-ray diffraction analysis. Data were collected on a Bruker APEX-II CCD area diffractometer and equipped with graphite monochromatic Mo K $\alpha$ radiation $(\lambda=71073 \AA)$ at $293(2)^{\circ} \mathrm{K}$. Cell refinement and data reduction were carried out by Bruker SAINT [14]. SHELXS-97 [15, 16] was used to solve structure (Table 1). The final refinement was carried out by full-matrix least-squares techniques with anisotropic thermal data for nonhydrogen atoms on F2. All the hydrogen atoms were placed in calculated positions. The crystal structure 4 (Figure 1) was finally refined with $R$ factor of $4.25 \%$ for 3362 unique reflections. Molecules were found to be packed in crystal lattice through intermolecular hydrogen bonding (Table 2).

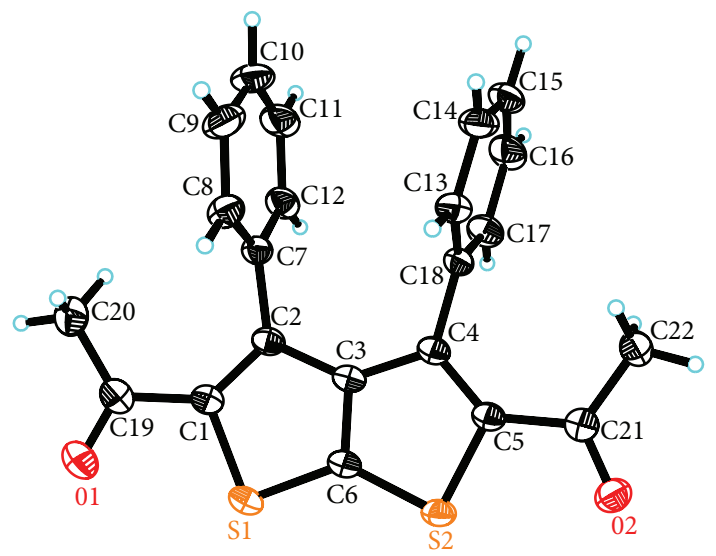

FIgUrE 1: The ORTEP diagram of the final X-ray model of compound 4 with displacement ellipsoids drawn at $30 \%$ probability level. $\mathrm{H}$-atoms were placed and not included in refinement.

TABLE 1: The crystal and experimental data of compound 4.

\begin{tabular}{lc}
\hline Empirical formula & $\mathrm{C}_{22} \mathrm{H}_{16} \mathrm{O}_{2} \mathrm{~S}_{2}$ \\
Formula weight & 376.47 \\
Temperature $(\mathrm{K})$ & $297(2)$ \\
Mo $K \alpha$ radiations, $\lambda$ & $0.71073 \AA$ \\
Crystal system & Monoclinic \\
Space group & $P 21 / n$ \\
$a$ & $9.3126(7) \AA$ \\
$b$ & $9.5867(7) \AA$ \\
$c$ & $20.2811(15) \AA$ \\
$\beta$ & $95.436(2)^{\circ}$ \\
Volume & $1802.5(2) \AA^{3}$ \\
$Z$ & 4 \\
Calculated density & $1.387 \mathrm{mg} / \mathrm{m}^{3}$ \\
Absorption coefficient & $0.309 \mathrm{~mm}{ }^{-1}$ \\
$F(000)$ & 784 \\
Crystal shape and color & Colorless, block \\
Crystal size & $0.54 \times 0.53 \times 0.30 \mathrm{~mm}$ \\
$\theta$ range & 2.02 to $25.50^{\circ}$ \\
$h / k / l$ & $-11,11 /-11,11 /-24,24$ \\
Reflections collected & 10407 \\
Reflections unique & 3362 \\
$\left(R_{\text {int }}\right)$ & 0.0261 \\
$R_{1}$ with $I>2 \sigma(I)$ & 0.0360 \\
$R_{2}$ with $I>2 \sigma(I)$ & 0.0925 \\
$R_{1}$ for all data & 0.0425 \\
$R_{2}$ for all data & 0.0980 \\
Goodness of fit & 1.042 \\
max/min $\rho$ e $\AA^{-3}$ & $0.193 /-0.176$ \\
\hline
\end{tabular}

2.4. Antifungal Activity. Tested sample was screened in vitro for its antifungal activity against various fungi, namely, Aspergillus fumigatus (RCMB 002568) and Candida albicans (RCMB 05036). The antifungal activity was performed by agar well diffusion method. 
TABLE 2: Hydrogen bonding data for compound 4.

\begin{tabular}{lcccccc}
\hline $\mathrm{D}$ & $\mathrm{H}$ & $\mathrm{A}$ & $\mathrm{D}-\mathrm{H}$ & $\mathrm{H} \cdots \mathrm{A}$ & $\mathrm{D} \cdots \mathrm{A}$ & $\mathrm{D}-\mathrm{H} \cdots \mathrm{A}$ \\
\hline $\mathrm{C} 10$ & $\mathrm{H} 10 \mathrm{~A}$ & $\mathrm{S1}^{\mathrm{a}}$ & 0.9300 & 2.8500 & $3.7542(2)$ & 161.00 \\
\hline
\end{tabular}

Symmetry codes: ${ }^{\mathrm{a}}-1 / 2+x, 1 / 2-y,-1 / 2+z$.

Fungal strains were grown in $5 \mathrm{~mL}$ sabouraud dextrose broth (glucose:peptone; 40:10) for 3-4 days to obtain $105 \mathrm{CFU} / \mathrm{mL}$ cells. The fungal culture $(0.1 \mathrm{~mL})$ was spread uniformly on the sabouraud dextrose agar plates by sterilized triangular folded glass rod. Plates were left for 5-10 min so the culture is properly adsorbed on the surface. Now small wells of size $4 \mathrm{~mm} \times 2 \mathrm{~mm}$ were cut into the plates with the help of well cutter and bottom of the wells was sealed with $0.8 \%$ soft agar to prevent the flow of test sample at the bottom of the well. $100 \mu \mathrm{L}$ of the tested samples $(10 \mathrm{mg} / \mathrm{mL})$ was loaded into the wells of the plates. Compound 4 dissolved in DMSO, while pure DMSO was also used as control. The plates were kept for incubation at $30^{\circ} \mathrm{C}$ for 3-4 days and then examined for the formation of zones of inhibition. The test was performed three times for each fungus. Amphotericin B was used as standard antifungal drug.

2.5. Antibacterial Activity. Antibacterial activities were investigated by using agar well diffusion method, against the Staphylococcus pneumonia (RCMB 010010) and Bacillus subtilis (RCMB 010067) \{as Gram-positive bacteria\} and Pseudomonas aeruginosa (RCMB 010043) and Escherichia coli (RCMB 0100052) \{as Gram-negative bacteria\}. The solution of $5 \mathrm{mg} / \mathrm{mL}$ of compound in DMSO was prepared for testing against bacteria. Centrifuged pellets of bacteria from $24 \mathrm{~h}$ old culture containing approximately 104-106 CFU (colony forming unit) per $\mathrm{mL}$ were spread on the surface of nutrient agar (typetone $1 \%$, yeast extract $0.5 \%, \mathrm{NaCl} 0.5 \%$, agar, and $1000 \mathrm{~mL}$ of distilled water, $\mathrm{pH}$ 7.0) which was autoclaved under $121^{\circ} \mathrm{C}$ for at least $20 \mathrm{~min}$. Wells were created in medium with the help of sterile metallic bores and then cooled down to $45^{\circ} \mathrm{C}$. The activity was determined by measuring the diameter of the inhibition zone (in $\mathrm{mm}$ ). $100 \mu \mathrm{L}$ of the tested samples $(10 \mathrm{mg} / \mathrm{mL})$ was loaded into the wells of the plates. Solution of compound was prepared in DMSO while DMSO was also loaded as control. The plates were kept for incubation at $37^{\circ} \mathrm{C}$ for $24 \mathrm{~h}$ and then the plates were examined for the formation of zone of inhibition. Each inhibition zone was measured three times by caliper to get an average value. The test was performed three times for each bacterium. Ampicillin and gentamicin were used as antibacterial standard drugs [17].

\section{Results and Discussion}

3.1. Title Compound 4 Was Synthesized as Depicted in Scheme 1, in 75\% Yield. The structure was deduced by combined use of IR, ${ }^{1} \mathrm{H}$-NMR, ${ }^{13} \mathrm{C}-\mathrm{NMR}$, and mass spectral data. Accordingly, the assigned structure was unambiguously established via single-crystal X-ray diffraction.

3.2. Crystal Structure of Compound 4. The asymmetric unit contains two molecules. The crystal structure of compound

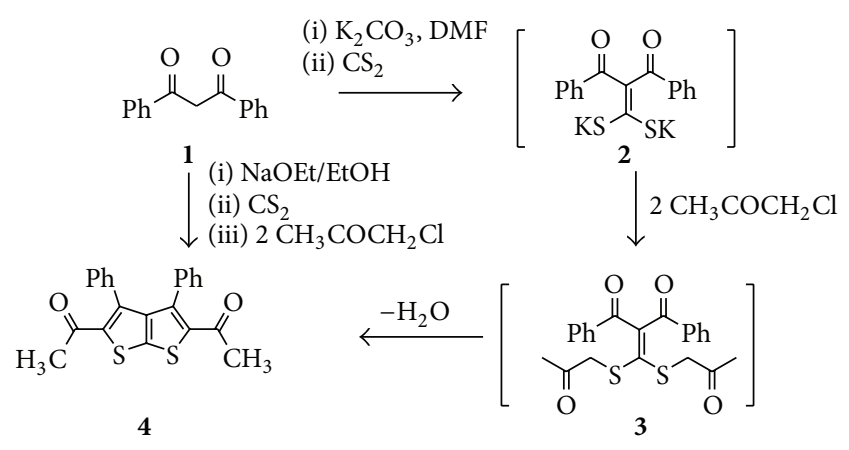

Scheme 1: Synthetic pathway towards title compound 4.

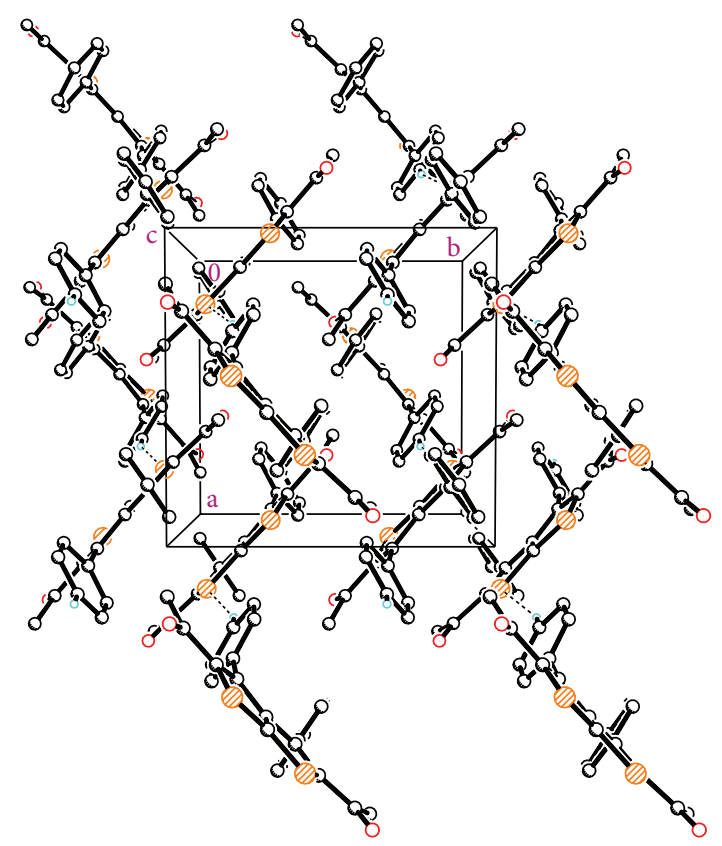

FIGURE 2: The crystal packing of compound 4. Dashed line indicates the intermolecular interactions. The hydrogen atoms not involved in intermolecular interactions are omitted for clarity.

4 is composed of two planner thiophene rings ( $\mathrm{S} 1 / \mathrm{Cl}-\mathrm{C} 3 / \mathrm{C} 6$ and $\mathrm{S} 2 / \mathrm{C} 3-\mathrm{C} 5 / \mathrm{C} 6)$, fused along $\mathrm{C} 3$ and $\mathrm{C} 6$ plane having two phenyl (C7-C12/C13-C18) rings and ethanone $(\mathrm{O} 1 / \mathrm{C} 19-$ C20/O2/C21-C22) moieties attached to $\mathrm{C} 1, \mathrm{C} 2, \mathrm{C} 4$, and $\mathrm{C} 5$ atoms (Figure 1). Two thiophene (S1/C1-C3/C6 and S2/C3$\mathrm{C} 5 / \mathrm{C} 6)$ and phenyl (C7-C12 and $\mathrm{C} 13-\mathrm{C} 18)$ rings are each planner with maximum deviation of $0.011(2) \AA$ for $\mathrm{C} 2$ and $\mathrm{C} 6$ atoms from the root mean square plane. The crystal molecules are linked via $\mathrm{C} 10-\mathrm{H} 10 \mathrm{~A} \cdots \mathrm{S} 1$ interaction to form chains arranged in a zigzag fashion along the $c$-axis (Figure 2).

3.3. Antimicrobial Activity of Compound 4. Compound 4 was evaluated against pathogenic microorganisms representing Gram-positive bacteria (Bacillus subtilis and Staphylococcus pneumoniae), Gram-negative bacteria (Pseudomonas aeruginosa and Escherichia coli), and fungi (Aspergillus fumigatus and Candida albicans), and the activities were compared with standard antibacterial and antifungal standard drug, 
TABle 3: Antimicrobial activity of compound 4.

\begin{tabular}{|c|c|c|c|c|c|c|}
\hline \multirow[b]{2}{*}{ Comp. number } & \multicolumn{2}{|c|}{ Gram-positive bacteria } & \multicolumn{2}{|c|}{ Gram-negative bacteria } & \multicolumn{2}{|c|}{ Fungi } \\
\hline & $\begin{array}{c}\text { Staphylococcus } \\
\text { pneumoniae }\end{array}$ & $\begin{array}{l}\text { Bacillus } \\
\text { subtilis }\end{array}$ & $\begin{array}{c}\text { Pseudomonas } \\
\text { aeruginosa }\end{array}$ & Escherichia coli & $\begin{array}{l}\text { Aspergillus } \\
\text { fumigatus }\end{array}$ & $\begin{array}{l}\text { Candida } \\
\text { albicans }\end{array}$ \\
\hline 4 & $12.9 \pm 0.63$ & $13.2 \pm 0.58$ & NA & $10.8 \pm 0.44$ & $18.7 \pm 0.36$ & $16.9 \pm 0.27$ \\
\hline Ampicillin & $23.8 \pm 0.2$ & $32.4 \pm 0.3$ & - & - & - & - \\
\hline Gentamicin & - & - & $17.3 \pm 0.1$ & $19.9 \pm 0.3$ & - & - \\
\hline Amphotericin B & - & - & - & - & $23.7 \pm 0.1$ & $25.4 \pm 0.1$ \\
\hline
\end{tabular}

Inhibition zones (mm).

NA: no activity.

specified in US pharmacopeia at $25 \mu \mathrm{g} / \mathrm{mL}$. Compound 4 showed a relatively moderate inhibitory effect against Grampositive bacteria (Bacillus subtilis and Staphylococcus pneumoniae) as compared to standard drug ampicillin. It also showed a relatively moderate inhibitory effect against Gramnegative bacteria (Escherichia coli), as comparable to that of the standard drug gentamicin. No activity was observed against Pseudomonas aeruginosa. Finally, compound $\mathbf{4}$ was also found to be active against fungi (Aspergillus fumigatus and Candida albicans), compared to the standard drug amphotericin B. The results obtained are summarized in Table 3.

\section{Conclusion}

The synthesis and characterization of a new $1,1^{\prime}-(3,4-$ diphenylthieno[2,3-b] thiophene-2,5-diyl)diethanone were successfully achieved in high yield. The structure of 4 was confirmed finally by single-crystal X-ray diffraction. Compound 4 showed activity effect against Gram-negative bacteria (Bacillus subtilis and Staphylococcus pneumoniae), Gram-positive bacteria (Escherichia coli), and antifungal activity against (Aspergillus fumigatus and Candida albicans). The pivotal compound 4 can be used as a synthon for new drugs with above cited.

\section{Conflict of Interests}

The authors have declared that there is no conflict of interests.

\section{Authors' Contribution}

The authors contributed equally to this work.

\section{Acknowledgments}

The authors extend their appreciation to the Deanship of Scientific Research at King Saud University for funding this work through the Research Group Project no. RGP-VPP-007.

\section{References}

[1] M. Heeney, C. Bailey, K. Genevicius et al., "Stable polythiophene semiconductors incorporating thieno[2,3-6] thiophene,"
Journal of the American Chemical Society, vol. 127, no. 4, pp. 1078-1079, 2005.

[2] S. H. Mashraqui, Y. S. Sangvikar, and A. Meetsma, "Synthesis and structures of thieno[2,3-b]thiophene incorporated [3.3] dithiacyclophanes. Enhanced first hyperpolarizability in an unsymmetrically polarized cyclophane," Tetrahedron Letters, vol. 47, no. 31, pp. 5599-5602, 2006.

[3] N. Shefer and S. Rozen, "The oxygenation of thieno[2,3b] thiophenes," Journal of Organic Chemistry, vol. 75, no. 13, pp. 4623-4625, 2010.

[4] P. R. J. Leriche, M. M. Turbiez, V. Monroche et al., "Linearly extended tetrathiafulvalene analogues with fused thiophene units as $\pi$-conjugated spacers," Journal of Materials Chemistry, vol. 13, no. 6, pp. 1324-1327, 2003.

[5] Y. N. Mabkhot, A. M. Al-Majid, A. Barakat, S. Alshahrani, and Y. Siddiqui, "1,1'-(3-methyl-4-phenylthieno[2,3-b] thiophene-2,5diyl)diethanone as a building block in heterocyclic synthesis. novel synthesis of some pyrazole and pyrimidine derivatives," Molecules, vol. 16, no. 8, pp. 6502-6511, 2011.

[6] Y. N. Mabkhot, A. Barakat, A. M. Al-Majid, and M. Iqbal Choudhary, "Synthesis of thieno[2,3-b]thiophene containing Bis-heterocycles-novel pharmacophores," International Journal of Molecular Sciences, vol. 14, no. 3, pp. 5712-5722, 2013.

[7] Y. N. Mabkhot, A. Barakat, A. M. A. Al Majid, S. Alshahrani, S. Yousuf, and M. I. Choudhary, "Synthesis, reactions and biological activity of some new Bis-heterocyclic ring compounds containing sulphur atom," Chemistry Central Journal, vol. 7, article 112, 2013.

[8] M. Heeney, C. Bailey, K. Genevicius et al., "Stable polythiophene semiconductors incorporating thieno[2,3-6] thiophene," Journal of the American Chemical Society, vol. 127, no. 4, pp. 1078-1079, 2005.

[9] S. H. Mashraqui, Y. S. Sangvikar, and A. Meetsma, "Synthesis and structures of thieno[2,3-b]thiophene incorporated [3.3] dithiacyclophanes. Enhanced first hyperpolarizability in an unsymmetrically polarized cyclophane," Tetrahedron Letters, vol. 47, no. 31, pp. 5599-5602, 2006.

[10] S. H. Mashraqui, Y. Sangvikar, M. Ashraf, S. Kumar, and E. T. H. Dâub, "Dipyridyl/pyridinium thieno[2,3-b]thiophenes as new atropisomeric systems. Synthesis, conformational analysis and energy minimization," Tetrahedron, vol. 61, no. 14, pp. 35073513, 2005.

[11] I. Jarak, M. Kralj, I. Piantanida et al., "Novel cyano- and amidino-substituted derivatives of thieno[2,3-b]- and thieno[3, $2-b]$ thiophene-2-carboxanilides and thieno $\left[3^{\prime}, 2^{\prime}: 4,5\right]$ thienoand thieno $\left[2^{\prime}, 3^{\prime}: 4,5\right]$ thieno $[2,3-c]$ quinolones: synthesis, photochemical synthesis, DNA binding, and antitumor 
evaluation," Bioorganic \& Medicinal Chemistry, vol. 14, no. 8, pp. 2859-2868, 2006.

[12] S. H. Mashraqui, H. Hariharasubrahmanian, and S. Kumar, "A convenient one-pot synthesis of 2,5-functionalized thieno[2,3b]- thiophenes using anhydrous potassium fluoride in dimethylformamide," Synthesis, no. 12, pp. 2030-2032, 1999.

[13] A. Comel and G. Kirsch, "Efficient one pot preparation of variously substituted thieno[2,3-b] thiophene," Journal of Heterocyclic Chemistry, vol. 38, no. 5, pp. 1167-1171, 2001.

[14] Bruker, SADABS, SMART and SAINT, Bruker AXS, Madison, Wis, USA, 2000.

[15] G. M. Sheldrick, "A short history of SHELX," Acta Crystallographica A, vol. 64, pp. 112-122, 2008.

[16] A. L. Spek, "Structure validation in chemical crystallography," Acta Crystallographica D, vol. 65, pp. 148-155, 2009.

[17] A. Smania, F. D. Monache, E. F. A. Smania, and R. S. Cuneo, "Antibacterial activity of steroidal compounds isolated from Ganoderma applanatum (Pers.) Pat. (Aphyllophoromycetideae) fruit body," International Journal of Medicinal Mushrooms, vol. 1 , no. 4 , p. $325,1999$. 

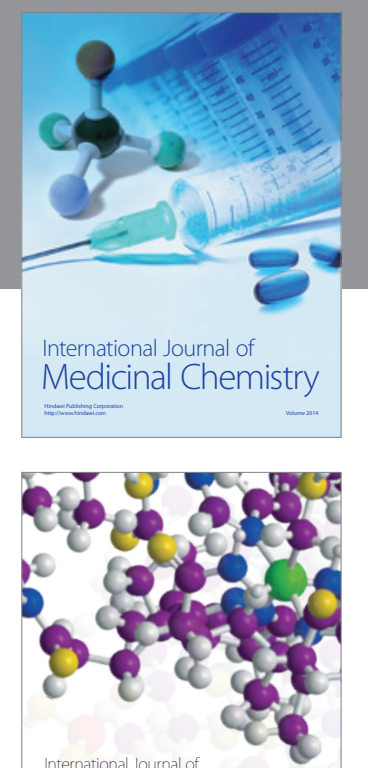

\section{Carbohydrate} Chemistry

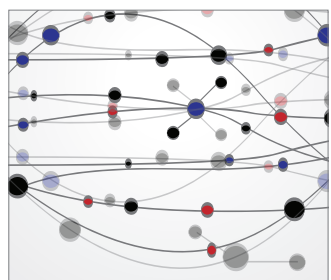

The Scientific World Journal
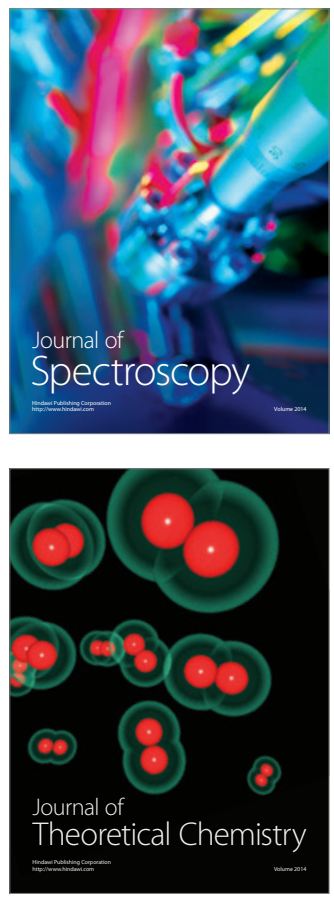
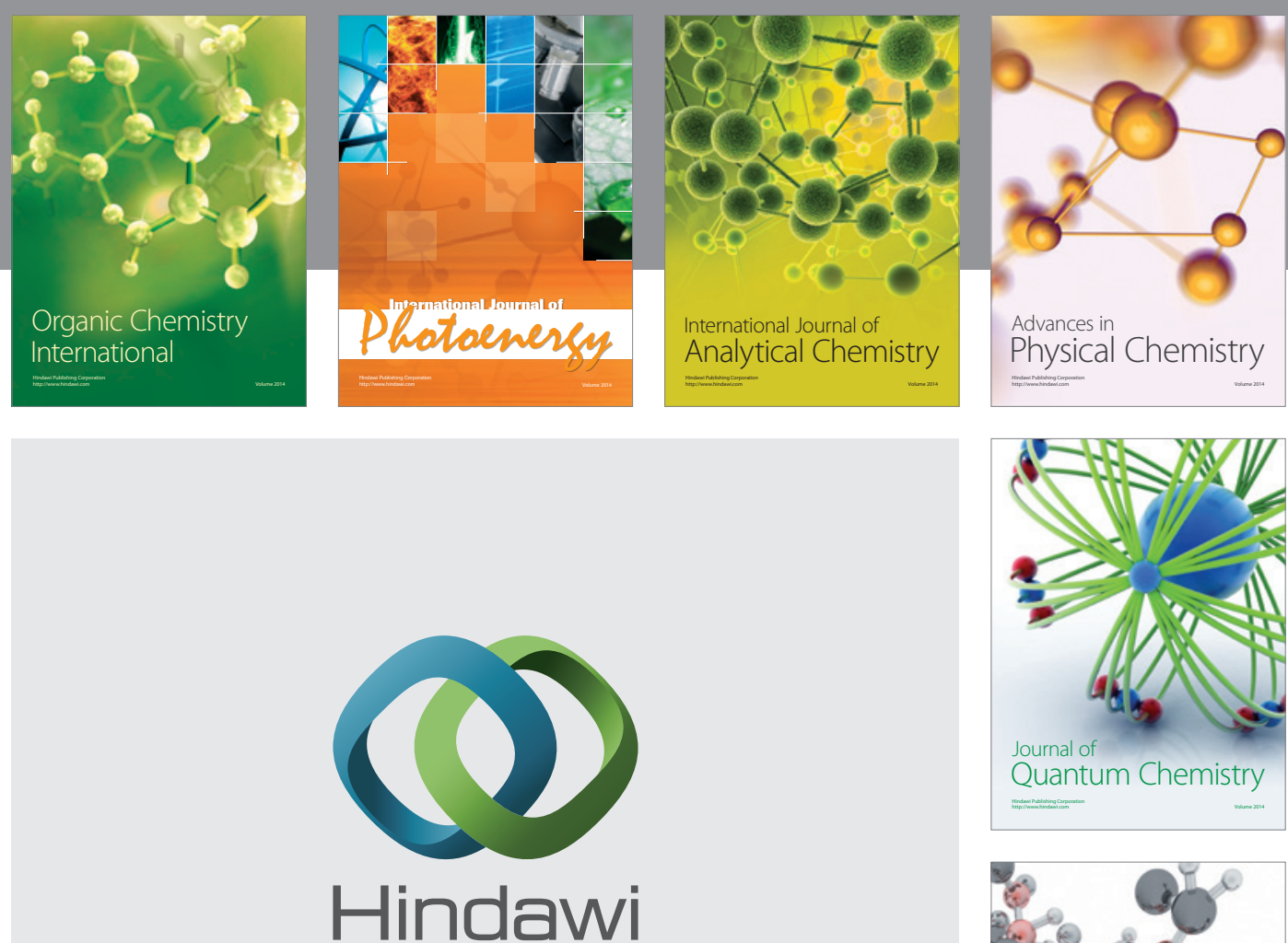

Submit your manuscripts at

http://www.hindawi.com

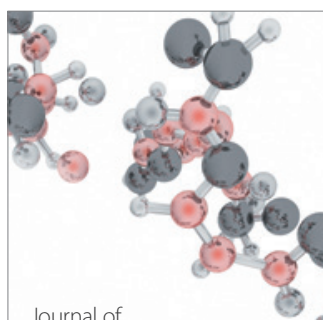

Analytical Methods

in Chemistry

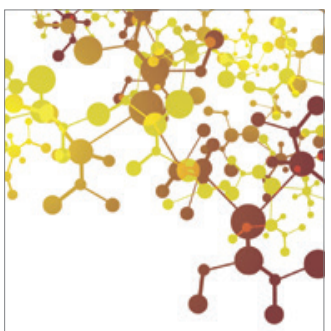

Journal of

Applied Chemistry

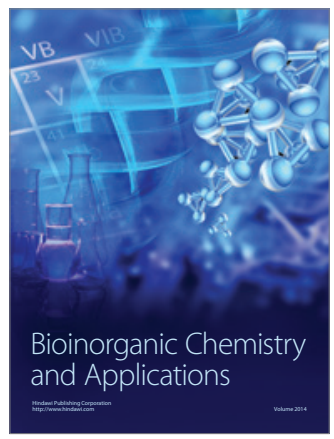

Inorganic Chemistry
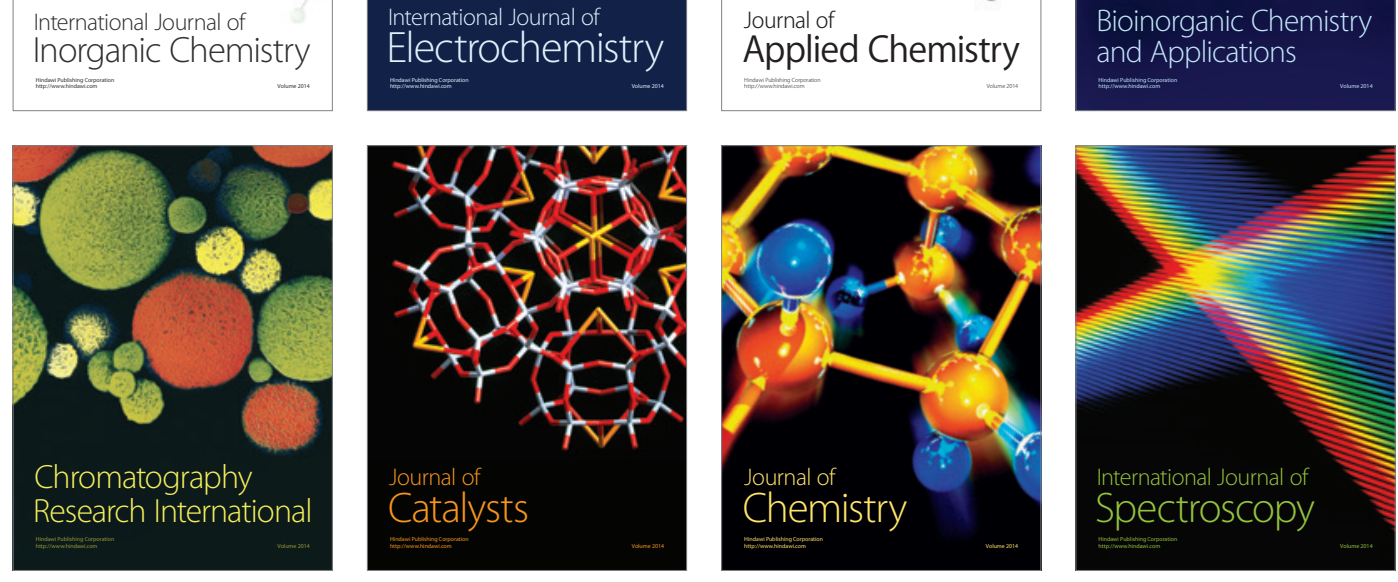